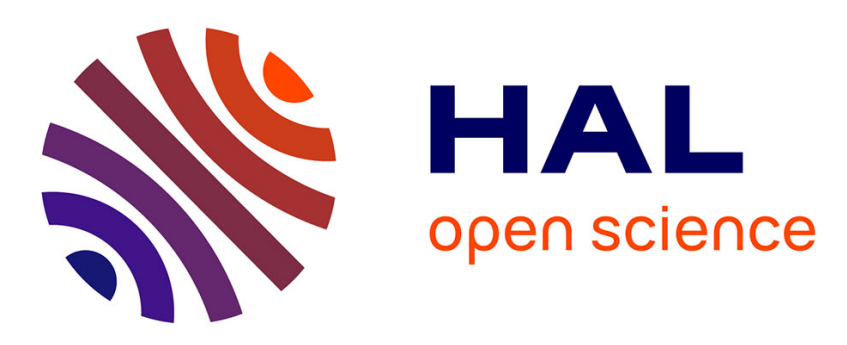

\title{
Unexpected formation of 2-alkynylpyridines from iodo-selenopyridines by selective activation of C Se over C I bonds
}

Christine Tran, Guillaume Lefèvre, Mansour Haddad, Virginie

Ratovelomanana-Vidal

\section{To cite this version:}

Christine Tran, Guillaume Lefèvre, Mansour Haddad, Virginie Ratovelomanana-Vidal. Unexpected formation of 2-alkynylpyridines from iodo-selenopyridines by selective activation of C Se over C I bonds. Catalysis Communications, 2019, 130, pp.105757. 10.1016/j.catcom.2019.105757 . hal03011778

\author{
HAL Id: hal-03011778 \\ https://hal.science/hal-03011778
}

Submitted on 18 Nov 2020

HAL is a multi-disciplinary open access archive for the deposit and dissemination of scientific research documents, whether they are published or not. The documents may come from teaching and research institutions in France or abroad, or from public or private research centers.
L'archive ouverte pluridisciplinaire HAL, est destinée au dépôt et à la diffusion de documents scientifiques de niveau recherche, publiés ou non, émanant des établissements d'enseignement et de recherche français ou étrangers, des laboratoires publics ou privés. 


\title{
Unexpected formation of 2-alkynylpyridines from iodo-selenopyridines by selective activation of $\mathrm{C}-\mathrm{Se}$ over $\mathrm{C}-\mathrm{I}$ bonds
}

\author{
Christine Tran, Guillaume Lefèvre, Mansour Haddad, Virginie Ratovelomanana-Vidal * \\ PSL Research University, Chimie ParisTech, CNRS, Institute of Chemistry for Life and Health Sciences, CSB2D 11 rue Pierre et Marie Curie, Paris 75005, France
}

\section{A R T I C L E IN F O}

\section{Keywords:}

Selenopyridines

Cross-coupling

Alkynylpyridines

Palladium

Copper

Alkynes

\begin{abstract}
A B S T R A C T
The synthesis of bicyclic 2-alkynylpyridines is performed in the presence of iodo-selenopyridines and terminal alkynes, using a palladium(II) catalyst, a copper(I) co-catalyst, and triethylamine as a base. This facile cross-coupling reaction leads to a wide variety of 2-alkynylpyridines in good yields. Mechanistic investigations provided by DFT calculations reveal that the reaction should involve a key selective activation of the $\mathrm{C}-\mathrm{Se}$ bond of the 2-selenopyridyl moiety by the in situ generated $\operatorname{Pd}(0)$ catalyst, preferentially to the C-I bond activation. A transmetalation step with copper acetylide, followed by a reductive elimination, affords the 2-alkynylpyridine product.
\end{abstract}

\section{Introduction}

2-Alkynylpyridines exhibit interesting biological properties as second mitochondria-derived activator of caspases (SMAC) mimetics. These molecules could be applied for the treatment and prevention of abnormal cell proliferation in cancer diseases [1,2]. Additionally, 2-alkynylpyridines represent synthetically relevant intermediates in organic synthesis, because their triple bonds could readily undergo diverse transformations, such as annulation [3], cyclization [4], or 1,3-dipolar cycloaddition [5]. In this context, these compounds contribute to the construction of a large array of heterocyclic frameworks, including azaindoles [6,7], furo[3,4-b]pyridines [8], indolizines [9], isoquinolines [10], aryl-substituted pyridines [11], and $N$-metallacycles [12]. As a result, the construction of functionalized 2-alkynylpyridines constitutes an attractive challenge, considering the synthetic and biological aspects of this scaffold.

We have recently developed a practical route to access iodo-selenopyridine derivatives [13]. We envisaged the functionalization of these selenopyridines, through a Sonogashira cross-coupling reaction. First, a reaction was performed with diarylselenium 1a and 1-hexyne (2a). Surprisingly, the desired product 4 was not obtained, but 2-alkynylpyridine 3a was isolated with $91 \%$ yield (Scheme 1).

In view of this unexpected result (Scheme 1), we focused our studies around the construction of 2-alkynylpyridines derivatives [14-25]. In addition, some DFT calculations were performed to enlighten the origin of this result, thus providing mechanistic insights into this access to the alkynylpyridine pattern.

\section{Results and discussion}

In light of the preliminary result, we thus investigated the scope of this reaction in the presence of diverse diarylselenium compounds. As depicted in Table 1, this method allows the access to a wide range of 2-alkynylpyridines from a large array of selenopyridines and diverse aryl/alkyl terminal alkynes. From selenopyridine 1a, alkynylpyridines 3a-e were obtained in good to excellent yields (71-91\%, Table 1, entries 1 to 5). The reaction was also well-tolerated in the presence of 2-ethynylpyridine, with $75 \%$ yield (entry 6 ). Cross-coupling reactions [26], performed in the presence of $\mathbf{1 b}$ [27], provided the desired compounds in 50 to $86 \%$ yields (Table 1, entries 7 to 11 ). The structure of $3 \mathbf{i}$ was confirmed by 2D NMR (NOESY experiment, $c f$. Supporting Information). It is noticeable that the reaction involving phenylacetylene led to pyridine derivatives with lower yields, probably due to steric effects (Table 1, entry 10). A good tolerance was also noted with the selenopyridines 1 c and 1d [27], bearing an oxygen atom or a diketone group, affording the expected alkynylpyridines 31-o with high yields (68 to $94 \%$ ). Moreover, the preparation of unsymmetrical alkynylpyridines was envisaged with selenium derivatives $\mathbf{1 e}$ and 1f [27], furnishing the corresponding products 3p and 3q in 97 and 54\% yield, respectively.

\footnotetext{
* Corresponding author.

Email address: virginie.vidal@chimie-paristech.fr (V. Ratovelomanana-Vidal)
} 


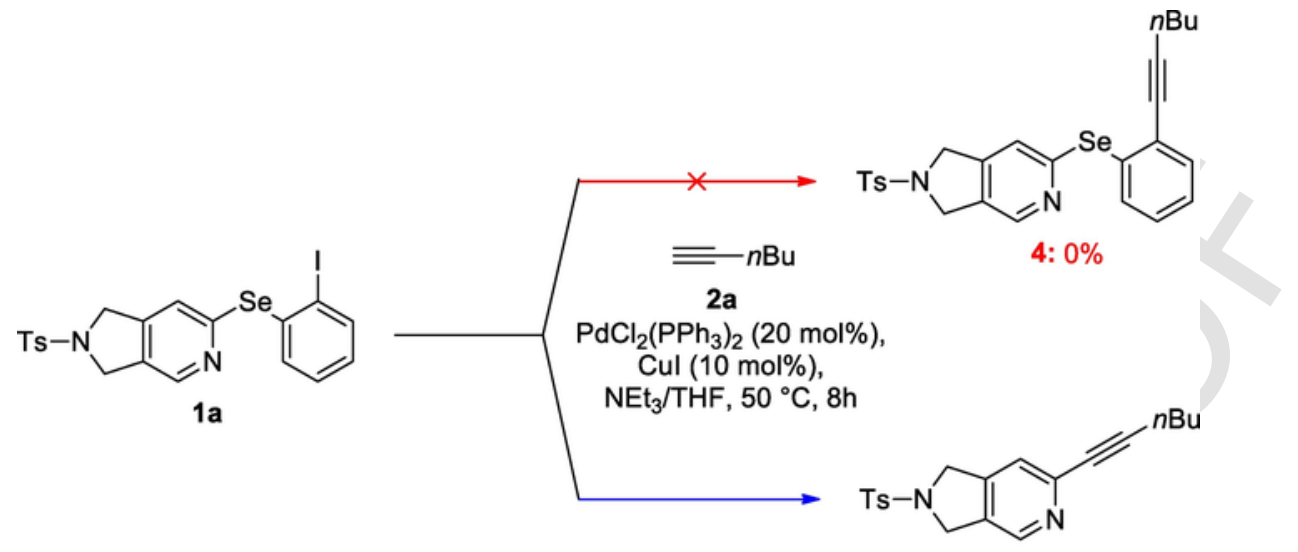

3a: $91 \%$

Scheme 1. Synthesis of 2-alkynylpyridine 3a

In the course of understanding the mechanism, the reaction between selenopyridine 1a and 1-hexyne (2a) was conducted without copper iodide and palladium catalyst (Table 2 , entry 1 ). No cross-coupling occurred and the starting materials (1a and $\mathbf{2 a}$ ) were recovered. Moreover, no reaction occurred in the presence of either $\mathrm{CuI}$ or $\mathrm{PdCl}_{2}\left(\mathrm{PPh}_{3}\right)_{2}$ alone (Table 2, entries 2 and 3). With solely CuI, the Glaser homo-coupling product was formed, suggesting that the presence of the homo-coupling diyne product arose from this off-cycle pathway [28,29]. An amine base was also required for the reaction, because the desired product $\mathbf{3 a}$ was not observed in the absence of triethylamine (Table 2, entry 4).

Replacing the -SeArI functional group by -SeMes delivered $\mathbf{3 a}$ in $42 \%$ yield under the same reaction conditions demonstrating that the iodo group is not mandatory for the transformation.

To explain the preferred alkynylation of the $\mathrm{C}$ - Se bond of the 2-selenopyridyl moiety compared to the classic alkynylation of the $\mathrm{C}-\mathrm{I}$ bond in the methodology described herein, DFT calculations were performed. $\mathrm{Pd}(0)\left(\mathrm{PMe}_{3}\right)_{2}, 2$-iodophenyl-2-pyridylselenide $\mathbf{A}$ and the preformed copper acetylide MeC $\equiv \mathrm{CCu}$ (THF) B were used as computational models. Three different pathways were investigated (Scheme 2) and are discussed thereafter.

The first pathway relies on a $\mathrm{Cu}(\mathrm{I}) / \mathrm{Cu}(\mathrm{III})$ cross-coupling catalytic cycle involving a key oxidative addition step of the copper catalyst into the $\mathrm{C}-\mathrm{Se}$ bond, excluding any role of the palladium in the catalytic process (Scheme 2a) [30]. A high $32.7 \mathrm{kcal}^{\mathrm{mol}}{ }^{-1}$ barrier has been computed for this pathway, which would be challenging to overcome under the reaction conditions. This explains why no reactivity is observed when the copper catalyst is used alone (Table 2, entry 2).

Subsequently, we sought to compare the respective barriers of the $\mathrm{C}$ - I (Scheme 2b) and C-Se (Scheme 2c) bond activation by oxidative addition at the $\mathrm{Pd}(0)$ catalyst. Computation of the oxidative addition of $\mathrm{Pd}(0)\left(\mathrm{PMe}_{3}\right)_{2}$ onto the $\mathrm{C}$ - I bond of $\mathbf{A}$ occurs through a classic three-center oxidative addition transition state $\left(\mathrm{TS}_{2}\right.$, Scheme $\left.2 \mathrm{~b}\right)$ with a modest $14.3 \mathrm{kcal} \cdot \mathrm{mol}^{-1}$ barrier, leading to the stable palladium(II) adduct $\mathbf{D}$ (exothermicity of $24.1 \mathrm{kcal} \cdot \mathrm{mol}^{-1}$ with respect to the reactants). Interestingly, the analysis of the potential energy surface for the oxidative addition occurring at the $\mathrm{C}-$ Se bond (Scheme $2 \mathrm{c}$ ) revealed that a pre-complex involving the diarylselenide $\mathbf{A}$ as a $\sigma$-acceptor ligand to the $\operatorname{Pd}(0)$ center could be formed in an endothermic step (formation of $\mathbf{E}$, with a computed $11.3 \mathrm{kcal} \cdot \mathrm{mol}^{-1}$ barrier). Complex $\mathbf{E}$ then evolves in a barrierless process toward the formation of a Meisenheimer-type intermediate $\mathbf{F}$, stabilized by $1.4 \mathrm{kcal} \cdot \mathrm{mol}^{-1}$ with respect to $\mathbf{E}$, which involves a palladium(II) center obtained by quaternization of the $\mathrm{C}_{2}$ atom of the pyridyl ring (Scheme 2c). Accordingly, an analysis of the Mulliken charge borne by the palladium atom and by the pyridyl moiety in reactants $\mathbf{A}$ and $\mathrm{Pd}(0)\left(\mathrm{PMe}_{3}\right)_{2}$ on one hand and on the stable Meisen- heimer adduct $\mathbf{F}$ on the other hand supports the hypothesis of a charge transfer from the palladium center of $\operatorname{Pd}(0)\left(\mathrm{PMe}_{3}\right)_{2}$ onto the pyridyl ring in the course of formation of $\mathbf{F}$. Charge borne by palladium indeed evolves from $+0.04|\mathrm{e}|$ in $\operatorname{Pd}(0)\left(\mathrm{PMe}_{3}\right)_{2}$ to $+0.48|\mathrm{e}|$ in $\mathbf{F}$, whereas the charge borne by the pyridyl group evolves from $+0.09|\mathrm{e}|$ in $\mathbf{A}$ to -0.30 $|\mathrm{e}|$ in $\mathbf{F}$. Adduct $\mathbf{F}$ prefigures the breaking of the $\mathrm{C}-$ Se bond, which increases from $1.93 \AA$ in $\mathbf{E}$ to $2.31 \AA$ in $\mathbf{F}$. Evolution of $\mathbf{F}$ finally provides the diarylpalladium(II) species $\mathrm{G}$, which formally represents the oxidative addition product of $\mathrm{Pd}(0)\left(\mathrm{PMe}_{3}\right)_{2}$ into the $\mathrm{C}-$ Se bond of $\mathbf{A}$. It is interesting to note that $\mathbf{G}$ is obtained with a small exothermicity with respect to the reactants (overall exothermicity of $2.3 \mathrm{kcal} \cdot \mathrm{mol}^{-1}$, Scheme 2c): this echoes the similar trend for the activation of $\mathrm{C}-\mathrm{S}$ bonds by oxidative addition of nickel(0) complexes, which proved to be easily reversible [31]. Comparison of the three pathways computed in Scheme 2 shows that the activation of the $\mathrm{C}-$ Se bond of $\mathbf{A}$ is preferred over the activation of the $\mathrm{C}-\mathrm{I}$ bond by $\mathrm{ca} .3 \mathrm{kcal} \cdot \mathrm{mol}^{-1}$ (which corresponds to the free energy difference between the rate-determining steps in Scheme $2 \mathrm{~b}$ and c, respectively leading to the formation of $\mathbf{T S}_{2}$ and $\mathbf{E}$ ). This can explain the selective functionalization of the $\mathrm{C}-\mathrm{Se}$ bond observed in this report.

These results in hand, the following pathway has been computed for the formation of the observed 2-alkynylpyridine from species G (Scheme 3). B can undergo a transmetalation reaction with G, affording the palladium(II) pyridyl-acetylide $\mathbf{H}$, as well as copper(I) selenide $\left(2-\mathrm{C}_{6} \mathrm{H}_{4} \mathrm{ISe}\right) \mathrm{Cu}(\mathrm{THF})$. The latter can then enter a new copper catalytic cycle to later afford copper(I) acetylide $\mathbf{B}$. $\mathbf{H}$ finally affords the observed 2-alkynylpyridine I via TS $_{3}$ (with a computed $14.3 \mathrm{kcal} \cdot \mathrm{mol}^{-1}$ barrier), with a global exothermicity of $26.0 \mathrm{kcal} \cdot \mathrm{mol}^{-1}$.

Taking into account of these mechanistic investigations, a plausible catalytic cycle for the transformation reported in this work is thus suggested in Scheme 4. This catalytic cycle displays two interconnected cycles, the first one relying on palladium catalysis, leading to the activation of the $\mathrm{C}-$ Se bond of the substrate, the second one relying on the formation of the copper acetylide involved in a key copper-to-palladium transmetalation step.

\section{Conclusion}

In summary, the unexpected formation of 2-alkynylpyridines obtained from iodo-selenopyridines through a palladium/copper co-catalytic system was reported. This transformation provides a broad array of substrates in good to excellent yields. Mechanistic studies demonstrated that the key step of this transformation is a selective activation of the $\mathrm{C}-$ Se bond of the starting iodo-selenopyridine, which undergoes oxidative addition of the palladium( 0 ) catalyst, whereas the $\mathrm{C}-\mathrm{I}$ bond remains unreactive. DFT calculations suggest that this selectivity 
Table 1

Synthesis of 2-alkynylpyridines via palladium-catalyzed cross-coupling.a

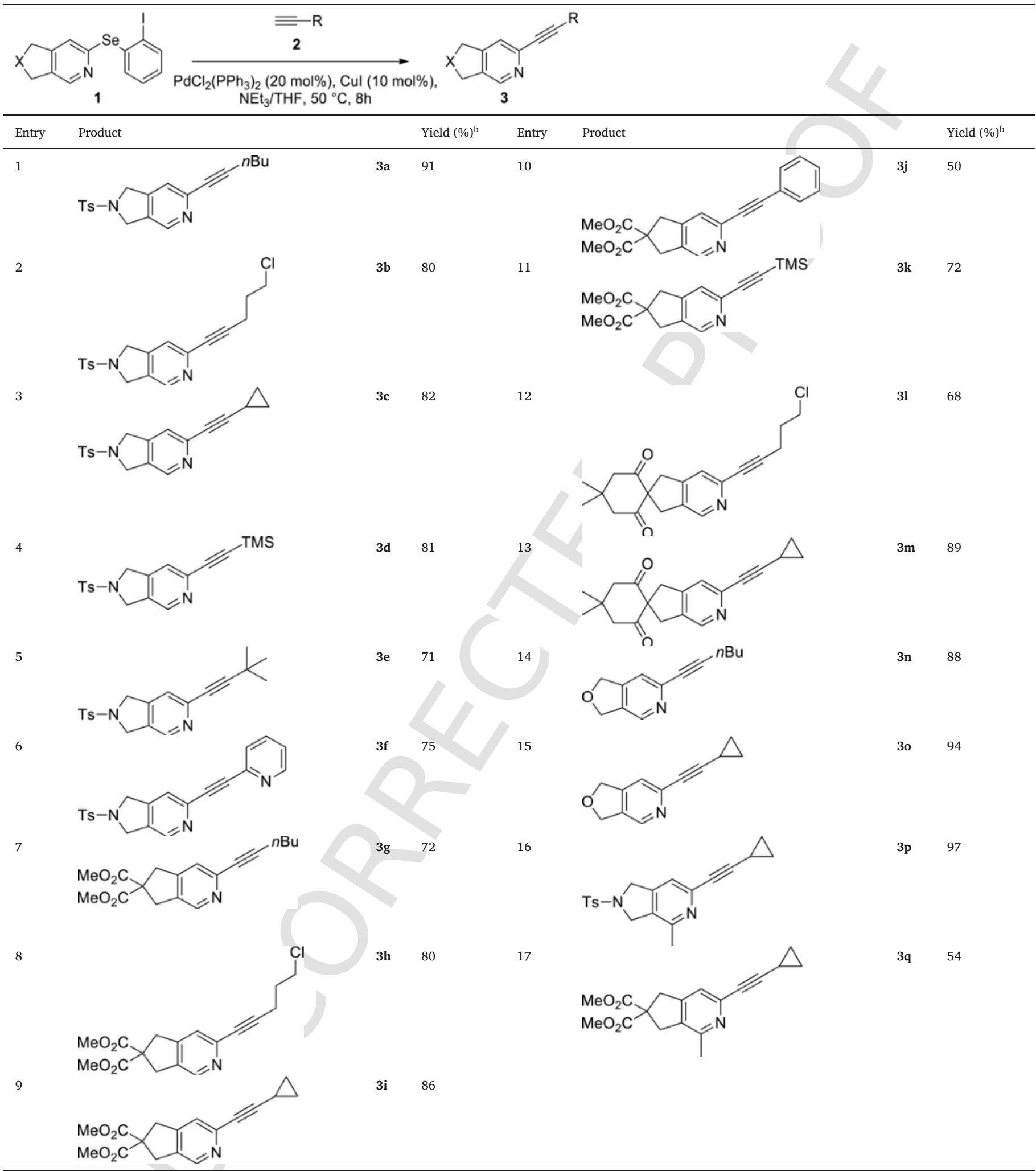

a Reaction conditions: 1 (0.1-0.3 mmol), 2 (4.0 equiv), $\mathrm{PdCl}_{2}\left(\mathrm{PPh}_{3}\right)_{2}(20 \mathrm{~mol} \%), \mathrm{CuI}(10 \mathrm{~mol} \%), \mathrm{NEt}_{3}(3 \mathrm{~mL}), \mathrm{THF}(3 \mathrm{~mL}), 50^{\circ} \mathrm{C}, 8 \mathrm{~h}$.

b Isolated yield.

originates from the existence of a low-energy Meisenheimer intermediate obtained in the course of the $\mathrm{C}-$ Se bond activation. This intermediate evolves toward a pyridylpalladium(II) species. A copper-to-palla- dium transmetalation between the latter and an acetylide copper(I) species followed by a reductive elimination leads to the 2-alkynylpyridine product. 
Table 2

Coupling reaction for mechanistic insights with selenopyridine 1a.

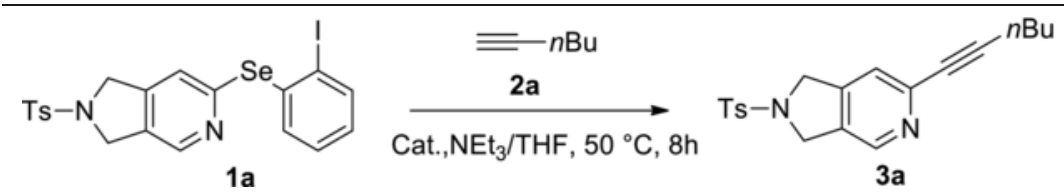

1a

3a

\begin{tabular}{|c|c|c|}
\hline Entry & Reaction conditions & Yield (\%) \\
\hline 1 & Without CuI and $\mathrm{PdCl}_{2}\left(\mathrm{PPh}_{3}\right)_{2}$ & $\mathrm{nr}$ \\
\hline 2 & With CuI only & $\mathrm{nr}$ \\
\hline 3 & With $\mathrm{PdCl}_{2}\left(\mathrm{PPh}_{3}\right)_{2}$ only & $\mathrm{nr}$ \\
\hline 4 & With CuI and $\mathrm{PdCl}_{2}\left(\mathrm{PPh}_{3}\right)_{2}$, without $\mathrm{NEt}_{3}$ & $\mathrm{nr}$ \\
\hline
\end{tabular}

a) $\mathrm{Cu}(\mathrm{I}) / \mathrm{Cu}(\mathrm{III})$ oxidative addition pathway
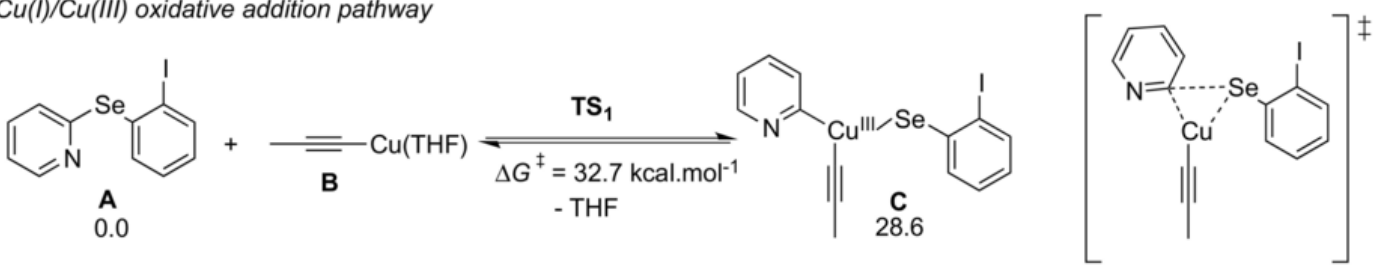

b) $P d(0) / P d(I I) C-I$ oxidative addition

$\mathrm{TS}_{1}$
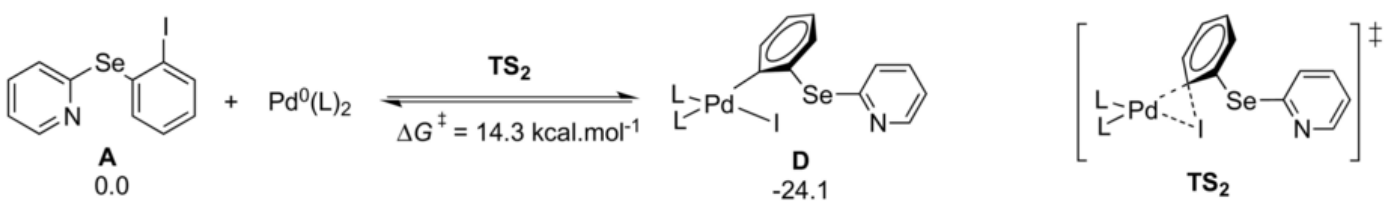

$\mathrm{TS}_{2}$

c) $\mathrm{Pd}(0) / \mathrm{Pd}(\mathrm{II}) \mathrm{C}$-Se oxidative addition

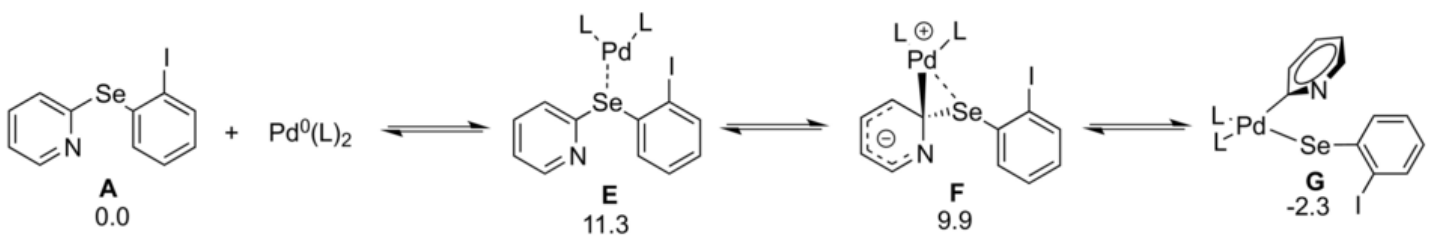

Scheme 2. Competitive pathways investigated by DFT computation.

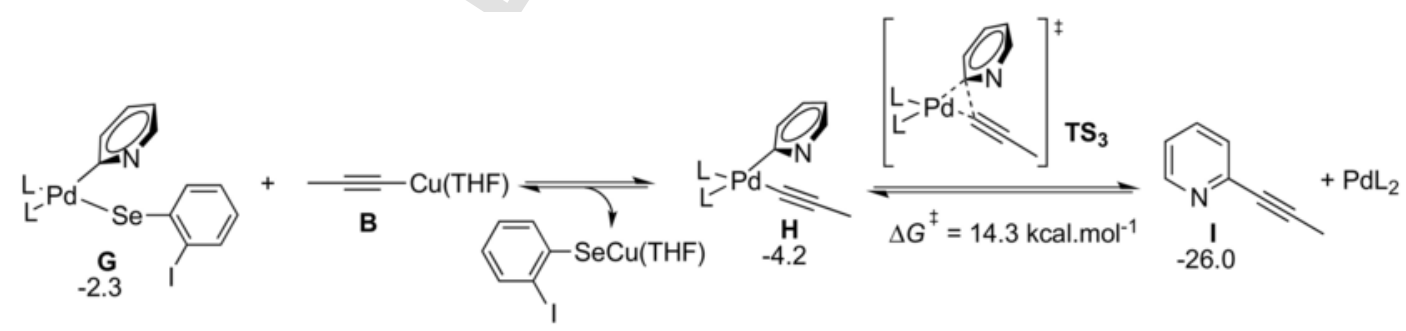

Scheme 3. DFT-computed pathway for the formation of I

\section{Experimental}

\subsection{General procedure for the synthesis of 2-alkynylpyridines}

In a round-bottom flask, $\mathrm{PdCl}_{2}\left(\mathrm{PPh}_{3}\right)_{2}(20 \mathrm{~mol} \%)$ and $\mathrm{CuI}(10 \mathrm{~mol} \%)$ were solubilized in THF $(1.5 \mathrm{~mL})$ and $\mathrm{NEt}_{3}(1.5 \mathrm{~mL})$. The yellow solution was stirred for $10 \mathrm{~min}$. A mixture of selenopyridine 1 (1.0 eq) and alkyne 2 (4.0 eq) in THF $(1.5 \mathrm{~mL})$ and $\mathrm{NEt}_{3}(1.5 \mathrm{~mL})$ was then added. The reaction was stirred at $50^{\circ} \mathrm{C}$ for $8 \mathrm{~h}$. The crude mixture was then quenched with a saturated aqueous solution of ammo- nium chloride. The organic layer was extracted with ethyl acetate (x3), washed with water, dried over $\mathrm{MgSO}_{4}$, filtered and concentrated under reduced pressure. The residue was purified by flash chromatography over silica gel to afford the corresponding alkynylpyridines.

\subsection{DFT calculations}

DFT calculations were performed using the Gaussian 09 code. See Gaussian 09, Revision D.01, M. J. Frisch et al., Gaussian, Inc., Wallingford CT, 2013, and see SI for additional details. 


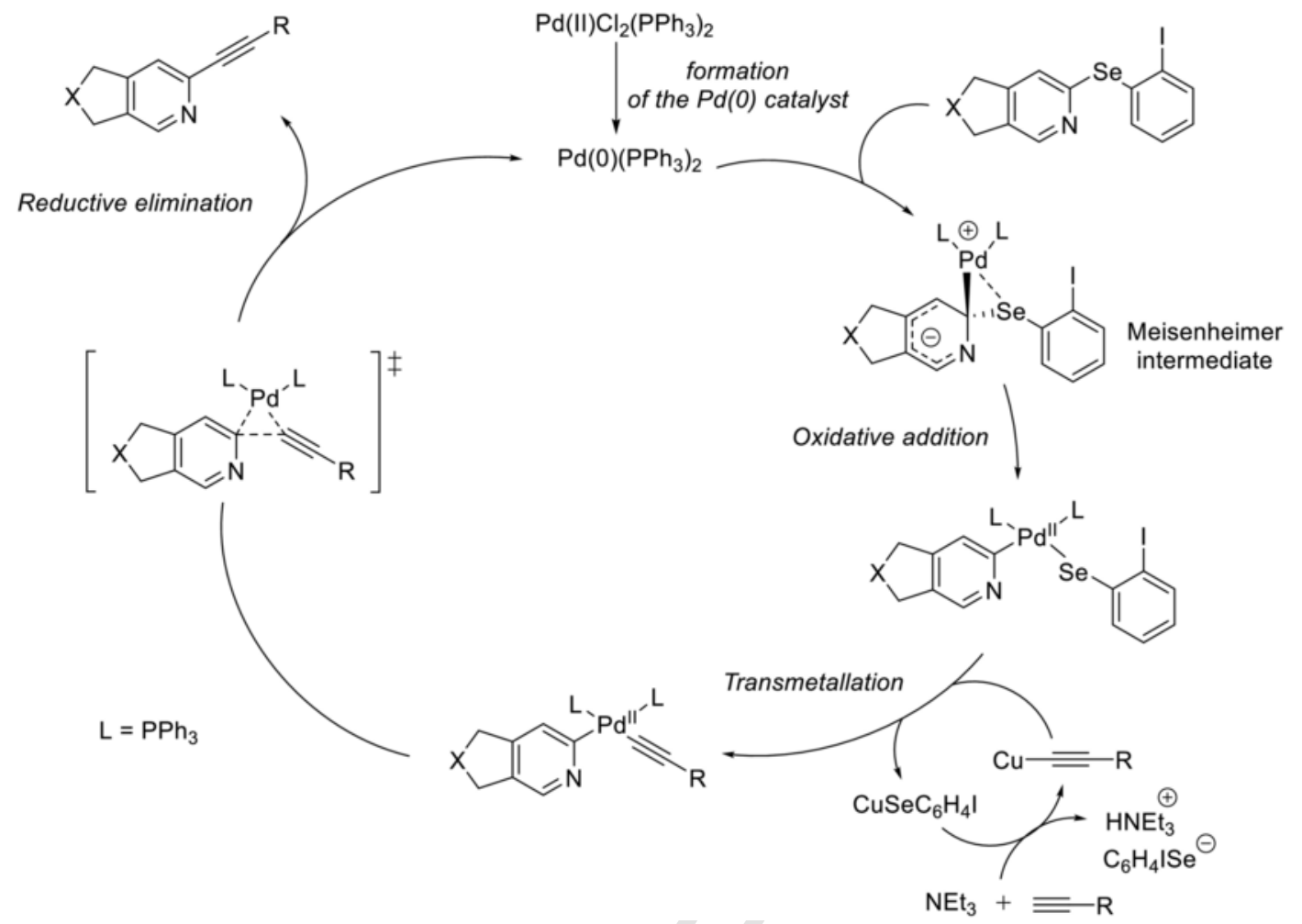

Scheme 4. Postulated reaction mechanism.

\section{Acknowledgements}

We thank the Ministère de l'Enseignement Supérieur de la Recherche et de l'Innovation, Chimie ParisTech (C.T.) and the CNRS for financial support. We are grateful to Dr. M.-N. Rager (Chimie ParisTech) for 2D NMR experiments.

\section{Appendix A. Supplementary data}

Supplementary data to this article can be found online at https:// doi.org/10.1016/j.catcom.2019.105757.

\section{References}

[1] U. Reiser, G. Bader, W. Spevak, A. Steffen, A.L. Parkes, US Pat. 0225567 A1, 2013

[2] U. Reiser, G. Bader, W. Spevak, A. Steffen, A.L. Parkes, US Pat. 8859541 B2, 2014.

[3] F. Roschangar, J. Liu, E. Estanove, M. Dufour, S. Rodríguez, V. Farina, E. Hickey, A. Hossain, P.-J. Jones, H. Lee, B.Z. Lu, R. Varsolona, J. Schröder, P. Beaulieu, J. Gillard, C.H. Senanayake, Tetrahedron Lett. 49 (2008) 363-366.

[4] M. Dell'Acqua, G. Abbiati, A. Arcadi, E. Rossi, Org. Biomol. Chem. 9 (2011) 7836-7848.

[5] K.A. Johnston, R.W. Allcock, Z. Jiang, I.D. Collier, H. Blakli, G.M. Rosair, P.D. Bailey, K.M. Morgan, Y. Kohno, D.R. Adams, Org. Biomol. Chem. 6 (2008) 175-186.

[6] S. Cacchi, G. Fabrizi, L.M. Parisi, J. Comb. Chem. 7 (2005) 510-512.

[7] C. Harcken, Y. Ward, D. Thomson, D. Riether, Synlett (20) (2005) 3121-3125.

[8] G.P. Jana, B.K. Ghorai, Tetrahedron 63 (2007) 12015-12025.

[9] D. Chernyak, S.B. Gadamsetty, V. Gevorgyan, Org. Lett. 10 (2008) 2307-2310.

[10] S. Mukherjee, G.P. Jana, B.K. Ghorai, J. Organomet. Chem. 694 (2009) 4100-4106.

[11] O.R. Abid, M. Nawaz, M.F. Ibad, R.A. Khera, V. Iaroshenko, P. Langer, Org. Biomol. Chem. 9 (2011) 2185-2191.

[12] J.W. Teo, V.S. Sridevi, W.K. Leong, Organometallics 33 (2014) 1174-1180.

[13] C. Tran, M. Haddad, V. Ratovelomanana-Vidal, Synthesis 51 (2019) 2532-2541.
[14] T. León, P. Quinio, Q. Chen, P. Knochel, Synthesis 46 (2014) 1374-1379.

[15] S. Roy, H. Plenio, Adv. Synth. Catal. 352 (2010) 1014-1022.

[16] H. Kim, P.H. Lee, Adv. Synth. Catal. 351 (2009) 2827-2832.

[17] G. Fabrizi, A. Goggiamani, A. Sferrazza, S. Cacchi, Angew. Chem. Int. Ed. 49 (2010) 4067-4070.

[18] G. Úr, T. Kálai, M. Balog, B. Bognár, G. Gulyás-Fekete, K. Hideg, Synth. Commun. 45 (2015) 2122-2129.

[19] W. Zhang, J. Cheng, Z. Huang, Q. Zhou, X. Chen, J. Qian, J. Chem. Res. 12 (2006) 781-782.

[20] Y. Kelgokmen, M. Zora, RSC Adv. 6 (2016) 4608-4621.

[21] K.C. Nicolaou, K. Namoto, A. Ritzén, T. Ulven, M. Shoji, J. Li, G. D'Amico, D. Liotta, C.T. French, M. Wartmann, K.-H. Altmann, P. Giannakakou, J. Am. Chem. Soc. 123 (2001) 9313-9323.

[22] C.S. Consorti, F.R. Flores, F. Rominger, J. Dupont, Adv. Synth. Catal. 348 (2006) 133-141.

[23] M. Zhang, T. Jia, C.Y. Wang, P.J. Walsh, J. Am. Chem. Soc. 137 (2015) 10346-10350.

[24] D. Bhatt, N. Patel, H. Chowdhury, P.V. Bharatam, A. Goswami, Adv. Synth. Catal. 360 (2018) 1876-1882.

[25] P.J. Hamzik, A.-S. Goutierre, T. Sakai, R.L. Danheiser, J. Organomet. Chem. 82 (2017) 12975-12991.

[26] Iodo-selenopyridine derivatives 1 (Table 1) were also evaluated in additional cross-coupling reactions. The Suzuki coupling was attempted with $1(\mathrm{X}=\mathrm{in}$ dene-1,3-dione) with phenyl boronic acid (2.0 equiv), $\mathrm{Pd}(\mathrm{OAc})_{2}(5 \mathrm{~mol} \%), \mathrm{K}_{2} \mathrm{CO}_{3}$ (3.0 equiv), CataCXium A ( 0.1 equiv) in $\operatorname{DMF}(0.3 \mathrm{M})$ at $90^{\circ} \mathrm{C}$ for $48 \mathrm{~h}$, affording the recovered starting material. The Heck reaction was performed with $1(X=2,2$-dimethyl-1,3-dioxane) in standard conditions (tert-butyl acrylate (3.5 equiv), $\mathrm{Pd}(\mathrm{OAc})_{2}(20 \mathrm{~mol} \%), \mathrm{K}_{2} \mathrm{CO}_{3}$ (1.0 equiv), $\mathrm{P}^{t} \mathrm{Bu}_{3}$ (2.0 equiv), DMA, $80^{\circ} \mathrm{C}, 48 \mathrm{~h}$ ), providing mainly degradation products.

[27] For the synthesis of $\mathbf{1 b}-\mathbf{1 f}$, see ref. 13

[28] C. Glaser, Ber. Dtsch. Chem. Ges. 2 (1869) 422-424.

[29] P. Siemsen, R.C. Livingston, F. Diederich, Angew. Chem. Int. Ed. 39 (2000) 2632-2657.

[30] M. Font, T. Parella, M. Costas, X. Ribas, For recent examples of $\mathrm{Cu}(\mathrm{I}) / \mathrm{Cu}(\mathrm{III})$ catalytic cycles involving the formation of $\mathrm{C}-$ Se bonds, Organometallics 31 (2012) 7976-7982.

[31] K. Osakada, M. Maeda, Y. Nakamura, T. Yamamoto, A. Yamamoto, J. Chem. Soc. Chem. Commun. (6) (1986) 442-443. 